\title{
EKSPERIMENTASI MODEL PEMBELAJARAN KOOPERATIF TIPE THINKING ALOUD PAIRS PROBLEM SOLVING (TAPPS) DAN TWO STAY TWO STRAY (TSTS) DITINJAU DARI GAYA KOGNITIF SISWA
}

\author{
Wahyu Kusumaningtyas ${ }^{1}$ \\ Institut Agama Islam Ma'arif NU Metro \\ mei201448@gmail.com
}

\begin{abstract}
This study aims to determine: (1) Which has the mathematics learning achievement better, a model of cooperative Thinking Aloud Pairs Problem Solving (Tapps), cooperative Two Stay Two Stray (TSTS) or direct instruction, (2) Which has the achievement better mathematics learning, students who have the cognitive style field independent (FI) or students who have the cognitive style field dependent (FD), (3) in each cognitive style, which one has the mathematics learning achievement better, a model of cooperative Thinking Aloud Pairs Problem Solving (Tapps), cooperative Two Stay Two Stray (TSTS) or direct learning, (4) on each of the learning model, which one has the achievement of better mathematics learning, students who have the cognitive style field independent (FI) or students who have the cognitive style of field dependent (FD.

This study is a quasi-experimental research. The populations in this study were all students of class VII SMP N 5 Metro 2015/2016 school year. The sampling technique was conducted by stratified cluster random sampling. The balance test performed using one way analysis of variance with different cells before carrying out a study of three groups of population. The data analysis technique used to test the hypothesis is two-way ANOVA with different cell with a $3 \times 2$ factorial design. Lilliefors prerequisite test method to test for normality and Bartlett methods for homogeneity.

From the analysis concluded: (1) cooperative learning model Thinking Aloud Pairs Problem Solving (Tapps) generates mathematics learning achievement better than cooperative learning ${ }^{1}$ Dosen Tarbiyah Program Studi Matematika Institut Agama Islam
Ma'arif NU Metro
\end{abstract}


model Two Stay Two Stray (TSTS), cooperative learning model Thinking Aloud Pairs Problem Solving (Tapps) generates mathematics learning achievement better than learning direct, cooperative learning model Two Stay Two Stray (TSTS) generates mathematics learning achievement better than learning Direct, (2) students with cognitive style Field Independent (FI) had mathematics learning achievement better than students with cognitive style Field Dependent (FD), (3) the individual cognitive style, cooperative learning model Thinking Aloud Pairs Problem Solving (Tapps) generates mathematics learning achievement better than cooperative learning model Two Stay Two Stray (TSTS ), cooperative learning model Thinking Aloud Pairs Problem Solving (Tapps) generates mathematics learning achievement better than learning direct, cooperative learning model Two Stay Two Stray (TSTS) generates mathematics learning achievement better than learning Direct (4) on each model of learning, mathematics achievement of students with cognitive style Field Independent (FI) have better mathematics learning achievement than students with cognitive style Field Dependent (FD).

Keywords: Tapps, TSTS, Direct learning, Learning Achievement, Cognitive Style.

\section{Abstrak}

Penelitian ini bertujuan untuk mengetahui : (1) manakah yang mempunyai prestasi belajar matematika lebih baik, model kooperatif tipe Thinking Aloud Pairs Problem Solving (TAPPS), kooperatif tipe Two Stay Two Stray (TSTS) atau pembelajaran langsung, (2) manakah yang mempunyai prestasi belajar matematika lebih baik, siswa siswa memiliki gaya kognitif field independent (FI) atau siswa yang memiliki gaya kognitif field dependent (FD), (3) pada masing-masing gaya kognitif, manakah yang mempunyai prestasi belajar matematika lebih baik, model kooperatif tipe Thinking Aloud Pairs Problem Solving (TAPPS), kooperatif tipe Two Stay Two Stray (TSTS) atau pembelajaran langsung, (4) pada masing-masing model pembelajaran, manakah yang mempunyai prestasi belajar matematika lebih baik, siswa siswa memiliki gaya kognitiffield independent (FI) atau siswa yang memiliki gaya kognitif field dependent (FD. 
Penelitian ini merupakan penelitian eksperimental semu. Populasi dalam penelitian ini adalah seluruh siswa kelas VII SMP N 5 Metro tahun pelajaran 2015/2016. Teknik pengambilan sampel dilakukan dengan stratified cluster random sampling. Sebelum melaksanakan penelitian terhadap ketiga kelompok populasi dilakukan uji keseimbangan menggunakan analisis variansi satu jalan dengan sel tak sama. Teknik analisis data yang digunakan untuk menguji hipotesis adalah anava dua jalan dengan sel tak sama dengan desain faktorial 3x2. Uji prasyarat dengan metode Lilliefors untuk uji normalitas dan metode Bartlett untuk uji homogenitas.

Dari hasil analisis disimpulkan : (1) model pembelajaran kooperatif tipe Thinking Aloud Pairs Problem Solving (TAPPS) menghasilkan prestasi belajar matematika lebih baik daripada model pembelajaran kooperatif tipe Two Stay Two Stray (TSTS), model pembelajaran kooperatif tipe Thinking Aloud Pairs Problem Solving (TAPPS) menghasilkan prestasi belajar matematika lebih baik daripada pembelajaran Langsung, model pembelajaran kooperatif tipe Two Stay Two Stray (TSTS) menghasilkan prestasi belajar matematika lebih baik daripada pembelajaran Langsung, (2) siswa dengan gaya kognitif Field Independent (FI) memiliki prestasi belajar matematika lebih baik daripada siswa dengan gaya kognitif Field Dependent (FD), (3) pada masing-masing gaya kognitif, model pembelajaran kooperatif tipe Thinking Aloud Pairs Problem Solving (TAPPS) menghasilkan prestasi belajar matematika lebih baik daripada model pembelajaran kooperatif tipe Two Stay Two Stray (TSTS), model pembelajaran kooperatif tipe Thinking Aloud Pairs Problem Solving (TAPPS) menghasilkan prestasi belajar matematika lebih baik daripada pembelajaran Langsung, model pembelajaran kooperatif tipe Two Stay Two Stray (TSTS) menghasilkan prestasi belajar matematika lebih baik daripada pembelajaran Langsung, (4) pada masing-masing model pembelajaran, prestasi belajar matematika siswa dengan gaya kognitif Field Independent (FI) memiliki prestasi belajar matematika lebih baik daripada siswa dengan gaya kognitif Field Dependent (FD).

Kata Kunci : TAPPS, TSTS, pembelajaran Langsung, Prestasi Belajar, Gaya Kognitif. 


\section{PENDAHULUAN}

\section{A. Latar Belakang}

Pendidikan merupakan salah satu kunci untuk membangun dan memajukan suatu bangsa.Pendidikan sebaiknya berubah dan berkembang sejalan dengan perubahan budaya.Sehingga, pendidikan dapat mengembangkan potensi dari siswa untuk menghadapi dan memecahkan masalah serta memenuhi tantangan masa depan dengan semakin berkembangnya ilmu pengetahuan, teknologi dan seni. Pendidikan juga ditekankan oleh Allah dalam firmannya dalam surat Al- Alaq ayat 1-5 yang berbunyi:

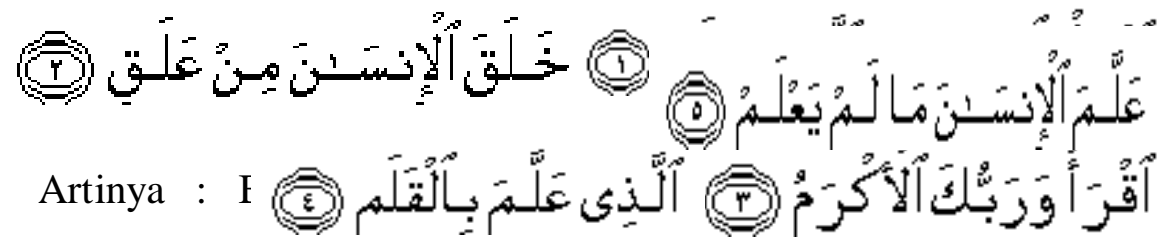

Menciptakan, Dia telah menciptakan manusia dari segumpal darah. Bacalah, dan Tuhanmulah yang Maha pemurah, Yang mengajar (manusia) dengan perantaran kalam, Dia mengajar kepada manusia apa yang tidak diketahuinya.

Berdasarkan beberapa ayat di atas sudah terlihat jelas bahwa Allah memberikan pengajaran bagi manusia untuk mengetahui apa yang tidak diketahui sebelumnya.

Selama ini pemerintah telah berupaya untuk mengembangkan pendidikan,misalnya dengan adanya perubahan dan penyempurnaan kurikulum yang dilakukan pemerintah dari 
dahulu hingga pada tahun 2006 diterapkannya Kurikulum Tingkat Satuan Pendidikan (KTSP). Dalam mengembangkan pendidikan, pemerintah membutuhkan kerja sama dan dukungan dari berbagai pihak yang berhubungan dengan pendidikan, salah satunya yaitu dari guru yang berperan sebagai pengajar dan pendidik. Guru diharapkan siap dan aktif dengan adanya perkembangan pendidikan.Karena adanya perkembangan pendidikan tersebutuntuk mengatasi masalah-masalah pendidikan yang terjadi.

Masalah-masalah pendidikan yang terjadi salah satunya berupa prestasi belajar yang rendah. Rendahnya prestasi belajar khususnya pada mata pelajaran matematika, dapat disebabkan banyak hal. Salah satu faktor penyebabnya dapat berupa model pembelajaran yang digunakan guru dalam pembelajaran kurang tepat, cara guru dalam menyampaikan materi pelajaran belum memberikan pemahaman kepada siswa.

Rendahnya prestasi belajar matematika juga ditemukan di kelas VII SMP N 5 Metro. Berdasarkan observasi yang telah diperoleh banyaknya siswa yang tuntas belajar (memperoleh nilai lebih besar atau sama dengan 67) hanya $40 \%$ pada materi segitiga dan segi empat.

Selama ini model pembelajaran yang dominan digunakan guru adalah model pembelajaran langsung. Pada pembelajaran langsung, pembelajaran lebih berfokus kepada guru atau teachercentered. Sehingga, guru yang aktif dalam menyampaikan materi sedangkan siswa hanya mendengarkan serta cenderung pasif dan tidak kreatif. Dominannya pembelajaran langsung dalam pembelajaran dikarenakan praktis dan tidak memerlukan alat, bahan dan waktu yang lama. 
Upaya yang mungkin dapat dilakukan adalah dengan menerapkan model pembelajaran yang tepat, yaitu model pembelajaran yang lebih melibatkan siswa dalam proses belajar, yang berupa aktivitas siswa dalam berpikir, menyusun konsep dan memberi makna tentang hal-hal yang sedang dipelajari. Salah satu model pembelajaran yang lebih melibatkan siswa dalam kegiatan pembelajaranyaitu model pembelajaran kooperatif. Menurut Trianto, pembelajaran kooperatif bernaung dalam teori kontruktivisme, dengan konsep siswa akan lebih mudah menemukan dan memahami konsep yang sulit jika mereka saling berdiskusi dengan temannya ${ }^{2}$.

Model pembelajaran kooperatif terdiri dari beberapa tipe, salah satunya yaitu model pembelajaran kooperatif tipe Thinking Aloud Pairs Problem Solving (TAPPS). Model pembelajaran kooperatif tipe Thinking Aloud Pairs Problem Solving (TAPPS) merupakan model pembelajaran kooperatif yang berorientasi pada kemampuan berpikir konstruktivisme, dimana dalam setiap kelompok terdiri dari problem solver dan listener yang keduanya dituntut berfikir keras secara berpasangan untuk menyelesaikan masalah.

Pate \& Miller mempertegas melalui hasil penelitiannya yang menyatakan bahwa:

"metacognitive instructional strategies, such as thinkaloud pair problem solving (TAPPS), can assist students with the organization and regulation of their information processing to improve their problem solving performance. Conceptually, the current study focuses on the improvement of students' performance on a complex problem-solving activity (troubleshooting)

2 Trianto. Model-Model Pembelajaran Inovatif Berorientasi Konstruktivistik.(Jakarta: Prestasi Pustaka, 2007). Hlm.56. 
by utilizing think-aloud pair problem solving as a strategy to invoke metacognitive thought". ${ }^{3}$

Hal tersebut berarti bahwa strategi pembelajaran metakognitif, seperti tipe Thinking Aloud Pair Problem Solving (TAPPS), dapat membantu siswa dengan mengorganisasi dan regulasi dalam pemrosesan informasi untuk meningkatkan kinerja pemecahan masalah mereka. Secara konseptual, pembelajaran ini berfokus pada peningkatan kinerja siswa pada kegiatan pemecahan masalah yang kompleks dengan memanfaatkan TAPPS sebagai strategi untuk mengembangkan pemikiran metakognitif dalam penyelesaian masalah.

Selain model pembelajaran kooperatif tipe TAPPS, ada juga model pembelajaran kooperatif yang lain yang setara jika dibandingkan dengan TAPPS. Model tersebut adalah model kooperatif tipe Two Stay Two Stray (TSTS). Pada TSTS setiap kelompok terdiri dari dua tamu dan dua tinggal yang memungkinkan setiap kelompok dapat saling berbagi informasi dengan kelompok lain. Saat diskusi intrakelompok maupun saat bertamu ke kelompok yang lain siswa dapat membangun pemahamannya, aktif bekerjasama dalam rangka mengembangkan, membangun pemikiran dan pengetahuanya untuk lebih memahami masalah pada materi pelajaran. Dengan melakukan diskusi intra dan antar kelompok, maka semua itu akan berjalan dengan baik dan mudah diperoleh sesuai yang diharapkan.

\footnotetext{
${ }^{3}$ Pate, M.L \& Miller, G. 2011. Effects of Think-Aloud Pair Problem Solving on Secondary-Level Students' Performance in Career and Technical Education Courses. Journal of Agricultural Education Volume 52, Number 1: 120131.hlm.121.
} 
Faktor lain yang dimungkinkan mempengaruhi rendahnya prestasi belajar matematika adalah gaya kognitif yang dimiliki siswa. Masing-masing siswa mempunyai ketertarikan terhadap suatu bidang ilmu tertentu, ada siswa yang tertarik dengan bidang ilmu matematika, tetapi ada juga siswa yang lebih menyukai bidang ilmu sosial. Hal tersebut merupakan karakteristik gaya kognitif siswa. Gaya kognitif menurut Nasution merupakan cara yang konsisten yang dilakukan siswa dalam menangkap stimulus/informasi, cara mengingat, berpikir, dan memecahkan soal. ${ }^{4}$

Berdasarkan uraian di atas, agar pembelajaran dapat dilaksanakan dengan baik sesuai dengan gaya kognitif siswa, dan untuk meningkatkan prestasi belajar matematika khususnya pada pokok bahasan segitiga dan segi empat, diperlukan suatu model pembelajaran matematika yang sesuai. Oleh karena itu, peneliti ingin mencobakan model kooperatif tipe Thinking Aloud Pairs Problem Solving (TAPPS) dan Two Stay Two Stray (TSTS) yang dinilai mampu mengatasi masalah yang telah dikemukakan di atas dan ingin membandingkan kedua model tersebut dengan model pembelajaran langsung yang biasa digunakan oleh guru.

\section{B. Rumusan Masalah}

Rumusan masalah dalam penelitian ini adalah: (1) Manakah yang memberikan kemampuan menyelesaikan soal cerita matematika lebih baik, model pembelajaran kooperatif tipe

\footnotetext{
${ }^{4}$ Nasution.. Berbagai Pendekatan Dalam Proses Belajar Mengajar. (Jakarta: bumi aksara, 2010).hlm.94
} 
Thinking Aloud Pairs Problem Solving (TAPPS), kooperatif tipe Two Stay Two Stray (TSTS) atau pembelajaran langsung?, (2) Manakah yang mempunyai prestasi belajar matematika lebih baik, siswa yang memiliki gaya kognitif field dependent atau siswa yang memiliki gaya kognitif field independent?, (3) Pada masing-masing gaya kognitif, manakah yang memberikan prestasi belajar matematika lebih baik, model kooperatif tipe Thinking Aloud Pairs Problem Solving (TAPPS), kooperatif tipe Two Stay Two Stray (TSTS) atau pembelajaran langsung?, (4) Pada masing-masing model pembelajaran, manakah yang mempunyai prestasi belajar matematika lebih baik, siswa memiliki gaya kognitif field dependent atau siswa yang memiliki gaya kognitif field independent?.

\section{Metode penelitian}

Berdasarkan permasalahan yang diteliti, jenis penelitian yang digunakan pada penelitian ini adalah penelitian eksperimental semu atau quasi eksperimental dengan desain faktorial $3 \times 2$ yang disajikan dalam Tabel 1.

Tabel 1 Rancangan Penelitian

\begin{tabular}{ccc}
\hline \multirow{2}{*}{ Model } & \multicolumn{2}{c}{ Gaya Kognitif (B) } \\
\cline { 2 - 3 } Pembelajaran (A) & Field independent & Field dependent \\
& $\left(\mathrm{b}_{1}\right)$ & $\left(\mathrm{b}_{2}\right)$ \\
\hline TAPPS $\left(\mathrm{a}_{1}\right)$ & $(\mathrm{ab})_{11}$ & $(\mathrm{ab})_{12}$
\end{tabular}


$\operatorname{TSTS}\left(\mathrm{a}_{2}\right)$

$(\mathrm{ab})_{21}$

$(a b)_{22}$

Langsung $\left(\mathrm{a}_{3}\right)$

$(\mathrm{ab})_{31}$

$(\mathrm{ab})_{32}$

Populasi dalam penelitian ini adalah seluruh siswa kelas VII SMP N 5 Metro. Pengambilan sampel dalam penelitian ini dilakukan dengan cara stratified cluster random sampling. Setelah dilakukan sampling diperoleh kelas VII A sebagai kelas eksperimen 1, kelas VII B sebagai eksperimen 2 dan kelas VII D sebagai kelas kontrol.

Terdapat dua variabel dalam penelitian ini yakni variabel bebas yaitu model pembelajaran dan gaya kognitif siswa dan variabel terikat yakni prestasi belajar matematika siswa. Untuk mengumpulkan data digunakan metode tes dan metode angket. Metode tes digunakan untuk mendapatkan mengevaluasi hasil belajar siswa setelah proses pembelajaran untuk mendapatkan prestasi belajar matematika siswa, metode angket digunakan untuk mengetahui gaya kognitif siswa.

Sebelum melakukan penelitian, terlebih dahulu dilakukan uji keseimbangan kemampuan awal siswa dengan uji analisis variansi satu jalan. Untuk melakukan uji analisis variansi satu jalan, terlebih dahulu melakukan uji prasyarat untuk anava yaitu uji normalitas populasi dengan metode Lilliefors dan uji homogenitas variansi populasi dengan uji Bartlett. Pengujian hipotesis penelitian, menggunakan teknik analisis variansi dua jalan dengan banyaknya baris 3 dan banyaknya kolom 2 dengan sel tak sama. Sebelum melakukan analisis variansi dua jalan terlebih dahulu melakukan uji prasyarat untuk anava yaitu uji normalitas dengan metode Lilliefors dan uji homogenitas dengan uji Bartlett. Jika 
diperlukan uji lanjut digunakan uji lanjut pasca analisis variansi dengan metode Scheffe (Budiyono) ${ }^{5}$.

\section{KAJIAN TEORI}

Prestasi belajar adalah hasil yang dicapai siswa pada aspek kognitif yang diperoleh selama proses pembelajaran pada waktu tertentu. Belajar adalah suatu proses membentuk pengetahuan baru yang bermakna dan diperoleh dengan mengembangan pemikiran siswa yang hasilnya dipengaruhi oleh pengalaman nyata siswa dengan lingkungannya. Pengertian matematika adalah ilmu yang mempelajari tentang bentuk, susunan, penalaran, konsep atau ideide abstrak yang tersusun secara sistematis yang berhubungan antara yang satu dengan yang lain.

Dari uraian di atas dapat disimpulkan bahwa prestasi belajar matematika adalah hasil yang dicapai siswa dari kegiatan pembelajaran mengenai bentuk, penalaran, konsep atau ide abstrak yang tersusun secara sistematis yang berhubungan antara yang satu dengan yang lain.

Model pembelajaran diartikan sebagai prosedur sistematis yang berisi langkah-langkah pembelajaran digunakan untuk mencapai tujuan pembelajaran. Suherman menyatakan bahwa pembelajaran kooperatif adalah pembelajaran yang melingkupi suatu kelompok kecil siswa yang bekerja sebagai sebuah tim untuk menyelesaikan masalah, menyelesaikan suatu tugas, atau mengerjakan sesuatu untuk mencapai tujuan bersama ${ }^{6}$. Hal ini sesuai dengan penelitian Whicker dan Bul yang menyatakan "Most

\footnotetext{
${ }^{5}$ Budiyono. 2009. Statistika Untuk Penelitian. Surakarta: UNS Press. Hlm.168

${ }^{6}$ Suherman. 2001. Strategi Pembelajaran Matematika Kontemporer. Bandung:

Universitas Pendidikan Indonesia.
} 
student indicated that they liked working in groups and appreciated getting help from other student, especialy for learning difficult concepts" 7 yang mengatakan bahwa kebanyakan siswa lebih menyukai bekerja secara kelompok dan berdiskusi dengan teman terutama dalam mempelajari konsep-konsep yang sulit.

Zakaria dan Iksan juga mengungkapkan "The use of cooperative learning as an alternative to traditional method is emphasized. Cooperative learning is grounded in the belief that learning is most effective when students are actively involved in sharing ideas and work cooperatively to complete academic tasks"8. Hal tersebut berarti pembelajaran kooperatif dapat menjadi alternatif untuk mengganti pembelajaran tradisional karena dengan pembelajaran kooperatif siswa lebih aktif untuk mengutarakan pendapatnya dan dapat bekerja sama dalam menyelesaikan tugas.

Model pembelajaran kooperatif merupakan suatu model pembelajaran yang membantu siswa dalam mengembangkan pemahaman, pengetahuan dan sikapnya sesuai dengan kehidupan yang ada didalam masyarakat, sehingga dengan adanya kerja sama antar anggota kelompok akan meningkatkan motivasi, produktifitas, dan perolehan belajar.

Model pembelajaran kooperatif tipe Thinking Aloud Pairs Problem Solving merupakan pengembangan dari model pembelajaran kooperatif, dimana siswa dituntut belajar berkelompok secara kooperatif dalam memecahkan masalah. Pate,

\footnotetext{
${ }^{7}$ Whicker, K.M. dan Bul, L. 1997. Cooperative Learning in the Secondary Mathematics Classroom. Journal of Education Research. Vol 91, No 1, 42-48.

${ }^{8}$ Zakaria, E. dan Iksan, Z. 2007. Promoting Cooperative Learning in Science and Mathematics Education. Eurasia Journal of Mathematics Science \& Technology Education. Vol 3, No 1, 35-39.
} 
Wardlow \& Johnson menegaskan bahwa "The thinking aloud pair problem solving (TAPPS) technique is a strategy for improving problem solving performance through probing and elaboration". Siswa dilatih dan dibiasakan untuk saling berbagi (sharing) pengetahuan, pengalaman, tugas dan tanggung jawab dalam memecahkan masalah ${ }^{9}$.

Menurut Felder dalam Nurhadi Hanuri pada model pembelajaran kooperatif tipe TAPPS ini siswa mengerjakan permasalahan yang mereka jumpai secara berpasangan dengan satu anggota pasangan berfungsi sebagai pemecah permasalahan dan yang lainnya sebagai pendengar ${ }^{10}$. Senada dengan pendapat Felder, dalam penelitian Dwi Cahyani N.A. menyatakan bahwa pada model TAPPS, peserta didik dibagi menjadi beberapa kelompok, setiap kelompok terdiri dari 2 pihak yaitu satu pihak menjadi problem solver (PS) dan pihak lainnya menjadi Listener (L) yang bertugas memancing PS untuk menjelaskan dan mengklarifikasi pemikirannya setelah memecahkan masalah ${ }^{11}$. Hal ini dipertegas oleh Louchhead dalam Pate \& Miller yang menyatakan bahwa: "The TAPPS strategy involves one student solving a problem while a listener asks questions to prompt the student to verbalize their thoughts and clarify their thinking”. yang berarti Strategi TAPPS melibatkan

\footnotetext{
${ }^{9}$ Pate, M.L., Wardlow, G.W., \& Johnson, D.M. 2004. Effects of Think-Aloud Pair Problem Solving on The Troubleshooting Performance of Undergraduate Agriculture Student's in a Power Technology Course. Journal of Agricultural Education Volume 45, Number 4: 1-11. Hlm.5

${ }^{10}$ Nurhadi Hanuri, 2011. Mencoba Metode Pembelajaran Kooperatif Model TAPPS. http://yohandi99.blogspot.com/2011/04/mencoba-metodepembelajaran-kooperatif.html. (Diakses Tanggal 10 Mei 2015)

${ }^{11}$ Dwi Cahyani N.A.,. Eksperimentasi Model Pembelajaran Kooperatif Tipe Thingking Aloud Pairs Problem Solving dan Group Investigation Terhadap Kemampuan Pemecahan Masalah Ditinjau dari Tipe Kepribadian. (Tesis. UNS. Surakarta, 2012). Hlm 47
} 
satu siswa sebagai pemecah masalah sementara yang lain menjadi pendengar, lalu pendengar mengajukan pertanyaan untuk mendorong siswa untuk mengolah pikiran mereka dan menjelaskan pemikiran mereka ${ }^{12}$.

Dari definisi tentang Thinking Aloud Pair Problem Solving di atas, dapat disimpulkan pengertian sederhana tentang TAPPS yaitu suatu model pembelajaran kooperatif yang berorientasi pada kemampuan berpikir konstruktivisme, dimana dalam setiap kelompok terdiri dari problem solver dan listener yang keduanya dituntut berpikir keras secara berpasangan untuk menyelesaikan masalah. Menurut Barkley et al. (Cerbin) menjelaskan bahwa

The Learning activity involves solving problems. Students Work in pairs and alternate roles. For Each problem one is the solver while the other is the listener. The Solver thinks Aloud-narrating his/her reasoning process-while solving the problem. The Listener prompts the solver to keep talking and asks for clarification but does not intervene to help ${ }^{13}$.

Hal ini, menyatakan bahwa TAPPS adalah kegiatan memecahkan masalah berpasangan, satu orang sebagia problem solver atau pemecah masalah dan yang lain sebagai pendengar dari solver. Problem solver berpikir keras memecahkan masalah menceritakan proses pemecahan masalah. Listener atau pendengar meminta solver mengklarifikasi pemecahan masalah yang

\footnotetext{
${ }^{12}$ Pate, M.L \& Miller, G. 2011. Effects of Think-Aloud Pair Problem Solving on Secondary-Level Students' Performance in Career and Technical Education Courses. Journal of Agricultural Education Volume 52, Number 1: 120-131. Hlm 123

${ }^{13}$ Cerbin, B. 2010. Collaborative Learning Techniques Workshop. Center for Advancing

Teaching dan Learning, UW- La Crosse
} 
dijelaskan tersebut dimana listener tidak membantu. Jadi, model pembelajaran ini merupakan salah satu model pembelajaran yang menekankan pada keaktifan siswa dalam menggunakan semua indera dan kemampuan berpikir untuk memahami konsep yang dipelajari

Model pembelajaran kooperatif tipe TSTS dikembangkan oleh Spencer Kogan pada tahun 1992 yang berarti dua tinggal dua bertamu bisa digunakan bersama dengan teknik kepala bernomor. Pembelajaran ini bisa digunakan dalam semua mata pelajaran dan untuk semua tingkatan usia peserta didik (Anita Lie) ${ }^{14}$. Menurut Miftahul Huda pembelajaran kooperatif tipe TSTS ini dapat dikombinasikan dengan teknik kepala bernomor dan dapat diterapkan untuk semua mata pelajaran dan tingkatan umur, serta memungkinkan setiap kelompok untuk saling berbagi informasi dengan kelompok-kelompok lain ${ }^{15}$.

Stuktur pembelajaran kooperatif tipe Two Stay Two Stray ini memberi kesempatan kepada kelompok untuk membagikan hasil dan informasi dengan kelompok lain. Banyak kegiatan belajar mengajar yang diwarnai dengan kegiatan-kegiatan individu. Siswa bekerja sendiri dan tidak diperbolehkan melihat pekerjaan siswa yang lain. Padahal dalam kenyataan hidup di luar sekolah, kehidupan dan kerja manusia saling bergantung satu dengan yang lainnya. Hal ini menunjukkan bahwa lima unsur proses belajar kooperatif yang terdiri atas: saling ketergantungan positif, tanggung jawab perseorangan, tatap muka, komunikasi antar kelompok dan

14 Anita Lie. Cooperatif Learning, Mempraktikkan Cooperatif Learning di Ruang-ruang Kelas. (Jakarta: PT Gramedia, 2007).hlm.61.

${ }^{15}$ Miftahul Huda. Model-Model Pengajaran dan Pembelajaran. (Yogyakarta: Pustaka Pelajar, 2013).hlm.140. 
evaluasi proses kelompok dapat terlaksana. Pada saat anggota kelompok bertamu ke kelompok lain maka akan terjadi proses pertukaran informasi yang bersifat saling melengkapi, dan pada saat kegiatan dilaksanakan maka akan terjadi proses tatap muka antar siswa dimana akan terjadi komunikasi baik dalam kelompok maupun antar kelompok sehingga siswa tetap mempunyai tanggung jawab perseorangan. (Anita Lie) ${ }^{16}$.

Pembelajaran langsung khusus dirancang untuk mengembangkan belajar siswa tentang pengetahuan prosedural dan pengetahuan deklaratif, yang dapat diajarkan selangkah demi selangkah. Pengetahuan deklaratif adalah pengetahuan tentang sesuatu, sedangkan pengetahuan procedural adalah pengetahuan, tentang bagaimana melakukan sesuatu. Proses pembelajaran matematika di kelas menjadi proses mengikuti langkah-langkah, aturan-aturan, serta contoh-contoh yang diberikan oleh guru. Dalam prakteknya model pembelajaran langsung lebih menekankan pada kemampuan untuk mengingat dan menghafal.

Gaya kognitif dalam penelitian ini diartikan sebagai karakteristik khas dari tiap individu untuk memproses informasi yang meliputi memahami, merasakan, mengingat, berpikir, dan menyelesaikan masalah serta biasanya terpola dalam waktu yang lama. Karena gaya kognitif merupakan suatu karakteristik maka setiap individu mempunyai gaya kognitif yang berbeda.

Penggolongan yang digunakan dalam penelitian ini adalah gaya kognitif field dependent-field independent. Gaya kognitif field dependent (FD) dan field independent (FI) mempunyai ciri khusus masing-masing yang dapat membedakannya satu sama lain.

${ }^{16}$ Anita Lie. Op. Cit .hlm.62. 


\section{HASIL PENELITIAN DAN PEMBAHASAN}

Setelah dilakukan uji normalitas diperoleh sampel berasal dari populasi yang berdistribusi normal, pada uji homogenitas diperoleh bahwa sampel berasal dari populasi yang homogen. Setelah uji normalitas dan homogenitas, dilakukan uji keseimbangan dan diperoleh bahwa sampel pada kelompok eksperimen 1, kelompok eksperimen 2 dan kelompok kontrol berasal dari populasi. Selanjutnya dilakukan uji hipotesis penelitian. Rerata masing-masing sel dan rerata marginal ditunjukkan pada Tabel 2.

Tabel 2. Rerata Masing-Masing Sel dan Rerata Marginal

\begin{tabular}{lccc}
\hline \multirow{2}{*}{ Model Pembelajaran } & \multicolumn{2}{c}{ Gaya Kognitif } & \multirow{2}{*}{ Rataan Marginal } \\
\cline { 2 - 3 } & FI & FD & \\
\hline TAPPS & 3,40 & 6,20 & 65,93 \\
TSTS & 2,54 & 6,21 & 63,38 \\
Langsung & 1,69 & 5,59 & 59,60 \\
Rataan Marginal & 6,32 & 6,00 & - \\
\hline
\end{tabular}

Rangkuman komputasi analisis variansi dua jalan dengan sel tak sama ditunjukkan pada Tabel 3.

Tabel 3. Rangkuman Analisis Variansi Dua Jalan dengan Sel Tak Sama

\begin{tabular}{|c|c|c|c|c|c|c|}
\hline SUMBER & JK & dK & RK & $\mathbf{F}_{\text {obs }}$ & $\mathbf{F}_{\boldsymbol{\alpha}}$ & $\begin{array}{l}\text { Keputusan } \\
\text { uji }\end{array}$ \\
\hline $\begin{array}{l}\text { Model } \\
\text { (A) }\end{array}$ & 20,27 & 1 & 20,72 & 4,12 & 4,00 & $\begin{array}{l}\mathrm{H}_{0 \mathrm{~A}} \\
\text { ditolak }\end{array}$ \\
\hline
\end{tabular}




\begin{tabular}{lcccccl}
\hline Gaya & & & & & & \\
$\begin{array}{l}\text { Kognitif } \\
\text { (B) }\end{array}$ & 1228,39 & 2 & 614,20 & 122,17 & 3,15 & $\begin{array}{l}\mathrm{H}_{0 \mathrm{~B}} \\
\text { ditolak }\end{array}$ \\
$\begin{array}{l}\text { Interaksi } \\
(\mathbf{A B})\end{array}$ & 17,93 & 2 & 8,89 & 1,78 & 3,15 & $\begin{array}{l}\mathrm{H}_{0 \mathrm{AB}} \\
\text { diterima }\end{array}$ \\
Galat & 33843,26 & 83 & 5,03 & - & - & - \\
Total & 1646,56 & 91 & - & - & - & - \\
\hline
\end{tabular}

Berdasarkan Tabel 3 dapat disimpulkan bahwa (a) model pembelajaran berpengaruh terhadap prestasi belajar matematika siswa, (b) gaya kognitif berpengaruh terhadap prestasi belajar matematika siswa, (c) tidak terdapat interaksi antara model pembelajaran dan gaya kognitif siswa.

Berdasarkan hasil perhitungan ANAVA diperoleh $H_{0 A}$ ditolak. Berarti tidak semua model pembelajaran memberikan pengaruh yang sama terhadap prestasi belajar matematika siswa, maka perlu dilakukan uji Scheffe. Perhitungan uji lanjut anava rerata antar baris ditunjukkan pada Tabel 4.

Tabel 4. Hasil Uji komparasai Rerata Antar Baris

\begin{tabular}{cccc}
\hline $\mathbf{H}_{\mathbf{0}}$ & $\mathbf{F}_{\text {hitung }}$ & $\mathbf{F}_{\text {tabel }}$ & Kesimpulan \\
\hline$\mu_{1 .}=\mu_{2 .}$ & 20,16 & 6,300 & $\mathrm{H}_{0}$ Ditolak \\
$\mu_{1 .}=\mu_{3 .}$ & 119,68 & 6,300 & $\mathrm{H}_{0}$ Ditolak \\
$\mu_{2 .}=\mu_{3 .}$ & 6,48 & 6,300 & $\mathrm{H}_{0}$ Ditolak \\
\hline
\end{tabular}

Dari Tabel 4 dan dengan memperhatikan Tabel 2 diperoleh (a) Terdapat perbedaan Prestasi belajar matematika siswa dengan model pembelajaran kooperatif tipe Thinking Aloud Pairs Problem Solving (TAPPS), selanjutnya dengan melihat rerata marginalnya 
maka dapat disimpulkan bahawa model pembelajaran kooperatif tipe Thinking Aloud Pairs Problem Solving (TAPPS) lebih baik daripada model pembelajaran kooperatif tipe Tipe Two Stay Two Stray (TSTS), (b) Terdapat perbedaan kemampuan menyelesaikan soal cerita matematika siswa dengan model pembelajaran kooperatif tipe Thinking Aloud Pairs Problem Solving (TAPPS), selanjutnya dengan melihat rerata marginalnya maka dapat disimpulkan bahwa model pembelajaran kooperatif tipe Thinking Aloud Pairs Problem Solving (TAPPS) lebih baik daripada pembelajaran langsung terhadap Prestasi belajar matematika siswa, (c) Terdapat perbedaan kemampuan menyelesaikan soal cerita matematika siswa dengan model pembelajaran kooperatif tipe Two Stay Two Stray (TSTS), selanjutnya dengan melihat rerata marginalnya maka dapat disimpulkan bahwa model pembelajaran kooperatif tipe Two Stay Two Stray (TSTS) lebih baik daripada pembelajaran langsung terhadap Prestasi belajar matematika siswa. Hal ini didukung hasil penelitian yang dilakukan oleh Dwi Cahyani Nur Apriyani yang menunjukan bahwa pembelajaran kooperatif tipe TAPPS memberikan kemampuan pemecahan masalah matematika siswa yang lebih baik dibandingkan dengan pembelajaran langsung ${ }^{17}$ dan penelitian yang dilakukan oleh Kristianingsih, yang menunjukan bahwa pembelajaran kooperatif tipe TSTS memberikan pengaruh yang lebih baik terhadap prestasi belajar dibandingkan dengan pembelajaran langsung ${ }^{18}$.

\footnotetext{
${ }^{17}$ Dwi Cahyani N.A., 2012. Eksperimentasi Model Pembelajaran Kooperatif Tipe Thingking Aloud Pairs Problem Solving dan Group Investigation Terhadap Kemampuan Pemecahan Masalah Ditinjau dari Tipe Kepribadian. Tesis. UNS. Surakarta

${ }^{18}$ Kristianingsing. 2013. Eksperimentasi model Two Stay Two Stray (TSTS) dan Make a Match Pada Pokok Bahasan Logaritma Ditinjau dari Konsep Diri
} 
Dari hasil perhitungan ANAVA diperoleh $H_{0 B}$ ditolak berarti tidak semua gaya kognitif siswa memberikan pengaruh yang sama terhadap prestasi belajar matematika siswa, maka perlu dilakukan uji lanjut ANAVA dengan metode Scheffe. Perhitungan uji lanjut anava rerata antar kolom ditunjukkan pada Tabel 5.

Tabel 5. Hasil Uji komparasai Rerata Antar Kolom

\begin{tabular}{cccc}
\hline $\mathrm{H}_{0}$ & $\mathrm{~F}_{\text {hitung }}$ & $\mathrm{F}_{\text {tabel }}$ & Kesimpulan \\
\hline$\mu_{.1}=\mu_{.2}$ & 61,32 & 6,300 & $\mathrm{H}_{0}$ Ditolak \\
& & & \\
\hline
\end{tabular}

Dari Tabel 5 dan dengan memperhatikan Tabel 2 diperoleh Terdapat perbedaan prestasi belajar matematika siswa yang memiliki gaya kognitif Field Independent (FI) dan siswa yang memiliki gaya kognitif Field Dependent (FD), sehingga dengan melihat rerata marginalnya prestasi belejar matematika siswa pada siswa yang memiliki Field Independent (FI) lebih baik daripada prestasi belajar matematika pada siswa yang memiliki Field Dependent (FD). Hasil penelitian ini sejalan dengan penelitan yang dilakukan Moertiningsih yang menunjukkan bahwa siswa dengan gaya kognitif field independen memiliki prestasi belajar yang lebih baik dibanding siswa dengan gaya kognitif field dependent. ${ }^{19}$

Dari perhitungan ANAVA diperoleh $H_{0 A B}$ diterima, maka tidak terdapat interaksi antara model pembelajaran dan gaya

Akademis Siswa SMK Kelompok Teknologi Kelas X Semester 1 di Kabupaten Kebumen. Tesis. UNS. Surakarta.

${ }^{19}$ Moertiningsih E. P. U. 2011. Eksperimentasi Model Pembelajaran Kooperatif Tipe Jigsaw Yang Dimodifikasi Ditinjau Dari Gaya Kognitif Siswa Kelas Viii Smp Negeri Di Kabupaten Grobogan Tahun 2010/2011. (Tesis. Uns. Surakarta, 2011). 
kognitif siswa terhadap prestasi belajar matematika siswa, sehingga tidak perlu melakukan uji lanjut ANAVA antar sel. Untuk tiap-tiap gaya kognitif, yang dikenai model pembelajaran kooperatif tipe TAPPS lebih baik dengan model pembelajaran kooperatif tipe TSTS, model pembelajaran kooperatif tipe TAPPS lebih baik dibandingkan dengan model pembelajaran langsung, model pembelajaran kooperatif tipe TSTS lebih baik daripada model pembelajaran langsung. Untuk tiap-tiap model pembelajaran, siswa dengan gaya kognitif field independent (FI) memiliki prestasi belajar matematika lebih baik dengan siswa dengan gaya kognitif field dependent (FD).

\section{SIMPULAN DAN SARAN}

Berdasarkan analisis data dan pembahasan dapat disimpulkan beberapa hal sebagai berikut: (1) Model pembelajaran kooperatif tipe Thinking Aloud Pairs Problem Solving (TAPPS) menghasilkan prestasi belajar matematika lebih baik daripada model pembelajaran kooperatif tipe Two Stay Two Stray (TSTS), model pembelajaran kooperatif tipe Thinking Aloud Pairs Problem Solving (TAPPS) menghasilkan prestasi belajar matematika lebih baik daripada pembelajaran Langsung, model pembelajaran kooperatif tipe Two Stay Two Stray (TSTS) menghasilkan prestasi belajar matematika lebih baik daripada pembelajaran Langsung, (2) Siswa dengan gaya kognitif Field Independent (FI) memiliki prestasi belajar matematika lebih baik daripada siswa dengan gaya kognitif Field Dependent (FD), (3) Pada masing-masing gaya kognitif, model pembelajaran kooperatif tipe Thinking Aloud Pairs Problem Solving (TAPPS) menghasilkan prestasi belajar 
matematika lebih baik daripada model pembelajaran kooperatif tipe Two Stay Two Stray (TSTS), model pembelajaran kooperatif tipe Thinking Aloud Pairs Problem Solving (TAPPS) menghasilkan prestasi belajar matematika lebih baik daripada pembelajaran Langsung, model pembelajaran kooperatif tipe Two Stay Two Stray (TSTS) menghasilkan prestasi belajar matematika lebih baik daripada pembelajaran Langsung, dan (4) Pada masing-masing model pembelajaran, prestasi belajar matematika siswa dengan gaya kognitif Field Independent (FI) memiliki prestasi belajar matematika lebih baik daripada siswa dengan gaya kognitif Field Dependent (FD).

Berdasarkan simpulan dari hasil penelitian di atas, peneliti memberikan beberapa saran sebagai berikut: (1) Bagi Guru Matematika pada penelitian menyimpulkan bahwa model pembelajaran kooperatif tipe Thinking Aloud Pairs Problem Solving (TAPPS) menghasilkan prestasi belajar matematika lebih baik daripada pembelajaran Langsung, sehingga guru disarankan menerapkan model pembelajaran kooperatif tipe Thinking Aloud Pairs Problem Solving (TAPPS) untuk pembelajaran di kelas terutama pada materi segitiga dan segi empat. Hal ini dikarenakan dengan menggunakan model kooperatif tipe Thinking Aloud Pairs Problem Solving (TAPPS) fokus pembelajarannya tergantung masalah yang dipilih sehingga siswa tidak saja mempelajari konsepkonsep yang berhubungan dengan masalah tetapi juga metode ilmiah untuk memecahkan masalah yang berhubungan dengan kehidupan sehari-hari. Selain itu, siswa bekerja dalam kelompok yang terdiri dari problem solver dan listener yang saling mendukung untuk menyelesaikan permasalahan. Melalui bantuan listener, problem solver 
dapat menyampaikan semua pemikiran dan ide untuk memecahkan permasalahan. Dengan demikian, seluruh anggota kelompok memahami langkah-langkah untuk menyelesaikan permasalahan beserta alasan mengapa memakai langkah seperti itu. Guru perlu memperhatikan gaya kognitif siswa sehingga dapat dihasilkan prestasi belajar matematika yang maksimal. (2) Kepala Sekolah: Kepala Sekolah selaku penentu kebijakan diharapkan dapat memberikan kesempatan kepada para guru untuk menerapkan dan mengembangkan model-model pembelajaran yang lebih efektif, khususnya model pembelajaran kooperatif tipe Two Stay Two Stray (TSTS) dan model pembelajaran kooperatif tipe Thinking Aloud Pairs Problem Solving (TAPPS). Sekolah diharapkan menyediakan fasilitas dan sumber belajar yang memadai, yang diperlukan dalam proses pembelajaran untuk menunjang kreativitas dan meningkatkan prestasi belajar matematika siswa sehingga saat peserta didik bekerja di dalam suatu kelompok akan menjadi lebih efektif dan dapat menghemat waktu yang terbuang. (3) Bagi para peneliti lain: penulis berharap agar para peneliti lain dapat meneruskan atau mengembangkan penelitian ini dengan penelitianpenelitian sejenis pada materi pokok yang lain atau dengan modelmodel pembelajaran lain misalkan Teams Assisted Individualization, Think Talk Write, Student Teams Achievement Divisions, dan lain-lain sehingga dapat menambah wawasan dan kualitas pendidikan yang lebih baik terkhusus pendidikan matematika. Peneliti lain juga dapat mengembangkan penelitian untuk faktor-faktor lain, misalnya kreatifitas, gaya belajar, keaktifan siswa dan lain-lain. 


\section{DAFTAR PUSTAKA}

Anita Lie. 2007. Cooperatif Learning, Mempraktikkan Cooperatif Learning di Ruang-ruang Kelas. Jakarta: PT Gramedia.

Budiyono. 2009.Statistika Untuk Penelitian. Surakarta: UNS Press.

Cerbin, B. 2010.Collaborative Learning Techniques Workshop. Center for Advancing Teaching dan Learning, UW-La Crosse.

Departemen Agama RI, 2004. Al-Qur'an dan Terjemahannya. Surabaya: Mekar,

Dwi Cahyani N.A.,. 2012. Eksperimentasi Model Pembelajaran Kooperatif Tipe Thingking Aloud Pairs Problem Solving dan Group Investigation Terhadap Kemampuan Pemecahan Masalah Ditinjau dari Tipe Kepribadian. Tesis. UNS. Surakarta.

Kristianingsing. 2013.Eksperimentasi model Two Stay Two Stray (TSTS) dan Make a Match Pada Pokok Bahasan Logaritma Ditinjau dari Konsep Diri Akademis Siswa SMK Kelompok Teknologi Kelas X Semester 1 di Kabupaten Kebumen. Tesis. UNS. Surakarta.

Miftahul Huda. 2013.Model-Model Pengajaran dan Pembelajaran. Yogyakarta: Pustaka Pelajar.

Moertiningsih E. P. U. 2011. Eksperimentasi Model Pembelajaran Kooperatif Tipe Jigsaw Yang Dimodifikasi Ditinjau Dari Gaya Kognitif Siswa Kelas Viii Smp Negeri Di Kabupaten Grobogan Tahun 2010/2011. Tesis. Uns. Surakarta. 2011.

Nasution. 2010.Berbagai Pendekatan Dalam Proses Belajar Mengajar. Jakarta: Bumi Aksara.

Hanuri, 2011. Mencoba Metode Pembelajaran Kooperatif Model TAPPS. http://yohandi99.blogspot.com/2011/04/mencoba- 
metode-pembelajaran-kooperatif.html. (Diakses Tanggal 10 Mei 2015)

Pate, M.L., Wardlow, G.W., \& Johnson, D.M. 2004.Effects of Think-Aloud Pair Problem Solving on The Troubleshooting Performance of Undergraduate Agriculture Student's in a Power Technology Course. Journal of Agricultural Education Volume 45, Number 4: 1-11.

Pate, M.L \& Miller, G. 2011.Effects of Think-Aloud Pair Problem Solving on Secondary-Level Students' Performance in Career and Technical Education Courses. Journal of Agricultural Education Volume 52, Number 1: 120-131.

Suherman. 2001.Strategi Pembelajaran Matematika Kontemporer. Bandung: Universitas Pendidikan Indonesia.

Trianto. 2007.Model-Model Pembelajaran Inovatif Berorientasi Konstruktivistik. Jakarta: Prestasi Pustaka.

Whicker, K.M. dan Bul, L. 1997.Cooperative Learning in the Secondary Mathematics Classroom. Journal of Education Research. Vol 91, No 1, 42-48.

Zakaria, E. dan Iksan, Z. 2007.Promoting Cooperative Learning in Science and Mathematics Education. Eurasia Journal of Mathematics Science \& Technology Education. Vol 3, No 1, 35-39. 
